Ignac Fock

\title{
Branka Kalenić Ramšak, Jasmina Markič, Barbara Pihler, Maja Šabec: Hispanistična razpotja: Rojas, Cervantes, Machado, García Márquez
}

Ljubljana: Znanstvena založba Filozofske fakultete Univerze v Ljubljani, Zbirka Razprave, 2013, 261 strani

Znanstvena monografija Hispanistična razpotja je pomemben mejnik na področju hispanistike v slovenskem prostoru. Dobrih trideset let obstajata hispanistični katedri Oddelka za romanske jezike in književnosti Filozofske fakultete Univerze v Ljubljani, kjer poučujejo vse štiri avtorice, ki pa so s pričujočo študijo štirih literarnih klasikov zajele pol tisočletja. Štiri poglavja monografije obravnavajo štiri temeljne avtorje, z njimi pa, vsaj posredno, tudi ključne zgodovinske in idejne trenutke za špansko govoreči svet: Fernando de Rojas - na prehodu iz srednjega v novi vek, ko si Španija na zemljevidu sveta zariše pot protagonista; Miguel de Cervantes - tudi po njegovi zaslugi sta šestnajsto in sedemnajsto stoletje $\mathrm{v}$ španskem imperiju, "v katerem sonce nikdar ne zaide", dobila ime zlati vek; Antonio Machado - na predvečer in v prvih desetletjih dvajsetega stoletja, ko se po dokončnem razpadu imperija Španija znajde v dotlej najhujši krizi duha in vrednot; nobelovec Gabriel García Márquez - v drugi polovici dvajsetega stoletja, ko pripovedna tradicija Latinske Amerike s tako imenovanim »boomom« simbolično zavzame mesto, ki je petsto let pred tem pripadalo Španiji.

Prvo poglavje je posvečeno Rojasovi Celestini ali Tragikomediji o Kalistu in Melibeji, delu, ki ga španska literarna zgodovina po pomenu umešča za Don Kihota in ob bok Junaški pesmi o Cidu. Raziskava se osredotoča na dvojno, protislovno pojmovanje ženske $\mathrm{v}$ srednjem veku, kar nujno vključuje tudi kulturnozgodovinski vpogled, in v segmentu literarnega dela, ki ta vidik izpostavlja, poskuša ugotoviti, ali oziroma na kakšen način upodobitev taiste antitetične pojavnosti ženske v Celestini že napoveduje renesančno in humanistično percepcijo $\mathrm{v}$ duhovnem in materialnem smislu, na kar ne nazadnje napeljuje letnica izdaje, 1499. Teoretski okvir študije za osnovo jemlje Bahtinov dialoški princip, dopolnjuje pa ga s kasnejšimi analitičnimi in interpretativnimi metodami medbesedilnosti. Izkaže se, da Rojas ni bil izviren v konceptualnem in idejnem smislu, saj je sledil mizogini in poveličevalski tako literarni kot širše kulturni srednjeveški tradiciji. Njegovo izvirnost, sodeč po sklepih raziskave, predstavlja način prepletanja in dialogizacije krščanske morale, dvorske ljubezni in celo medicinske vede, ki napoveduje humanizem. 
Drugo poglavje, ki skozi skrbno strukturirano faktografijo ter njeno širšo zgodovinsko in kulturno interpretacijo govori o življenju in delu avtorja prvega modernega romana, Miguelu de Cervantesu, je izrazito literarnozgodovinsko, v metodološkem smislu pa biobibliografsko. To se ob popolni odsotnosti kakršnihkoli avtobiografskih zapisov izkaže za neobhodno; da tak, z aktualnimi znanstvenimi dognanji tudi teoretično dopolnjen pristop ravno v Cervantesovem primeru prinaša najtrdnejša izhodišča za nadaljnje raziskave, pa nam študija dokaže, ko izriše njegov humanistični portret na temelju še vedno ne povsem nedvoumnih biografskih dognanj in zlasti njegovih literarnih del. Ker gre za enega ključnih avtorjev ne le v literarnovednih študijah, temveč tudi v šolskem kurikulumu, kjer je eden redkih hispanističnih predstavnikov, je še posebej pomembno, da ta del študije razjasni in ovrže morebitne netočnosti in zmotne interpretacije.

V tretjem poglavju se študija teoretsko razcepi, a hkrati filološko združi, saj v osnovi literarno temo, lirski diskurz, proučuje skozi jezikoslovno prizmo. Ugotavlja namreč principe ubesedovanja časovnosti v poeziji Antonia Machada, ki ga na podlagi njegove poetike opredeli prav kot "pesnika časa «. Metodološko ta raziskava izhaja iz proučevanja fikcijskega sporazumevanja v liriki, torej iz pragmatičnojezikoslovnega postulata, da je tudi pesniško besedilo sporočanjsko dejanje, katerega edinstvenost pa je $\mathrm{v}$ konkretnem primeru posledica specifične rabe španskih glagolskih paradigem, predvsem glede na njihove časovno-modalne vrednosti. Na konceptualno-idejnih izhodiščih ter proučevanju poetike in lirskega diskurza je v zaključku osnovana teorija o temeljnih postopkih izražanja časovnih odnosov v španskih lirskih diskurzih, poimenovana »mehanizmi diskurzivnega učasovljanja v poeziji «.

Tudi zadnje, četrto poglavje, ki se ukvarja z romanoma La hojarasca in Sto let samote Gabriela Garcíe Márqueza, se postavlja med, prvenstveno, jezikoslovje, ker analizira glagolske strukture kot nosilce časovno-aspektualnih pomenov, in literarno vedo, saj izbiro korpusa utemeljuje $\mathrm{z}$ umestitvijo $\mathrm{v}$ pisateljev opus. Ta časovnoprostorski kontekst naj bi določal pripovedno tehniko in slogovne prvine, med katerimi je poglavitna prav specifična raba glagolskih paradigem in, še posebej v španščini, glagolskih perifraz. Študija med prvim romanom, ki je izšel leta 1955, in drugim, ki nosi letnico 1967, dokaže kontekstualno in narativno poglabljanje prek navedenih prijemov, v prvi vrsti zaradi razvejanih časovnih, aspektualnih in naklonskih vrednosti glagolskih struktur v španščini.

Kljub temu da je monografija očitno osnovana na literarnih temeljih, od kanonskih del do tistih manj poznanih, je izrazito interdisciplinarna. Glede na posamezno problematiko in začrtane raziskovalne smernice se sicer opira zdaj na literarnoteoretska oziroma literarnozgodovinska, zdaj na jezikoslovna metodološka 
izhodišča, toda koherenten spoj obojega na ravni celotnega dela lahko razumemo kot željo po bolj filološkem pristopu. Tendenco, ki je še posebej opazna v tretjem in četrtem poglavju, bi lahko videli tudi kot premik na metodološkem področju, ki ga študija utemeljuje kot "pragmatični pogled«. V teh dveh raziskavah se implicitno nakazujeta nuja in izziv kontrastivne obdelave, saj bi lahko prenos teh mehanizmov v slovenski jezik vsaj deloma prišel do aplikativnega odseva, torej temeljitega vpogleda $\mathrm{v}$ morebiten prevajalski proces, kar gre, $\mathrm{v}$ smislu medkulturnosti, bržkone razumeti kot enega od ciljev te monografije v slovenskem prostoru.

Bistveni doprinos tematsko razvejanih, a sovisnih Hispanističnih razpotij je poleg pojmovnega tudi terminološki okvir za nadaljnje raziskave, primarno seveda na področju hispanistike, vendar pa je neposredno prav tako vezan na slovensko literarno vedo in jezikoslovje, ki ju dopolnjuje in kontrastira. Znanstvena monografija Hispanistična razpotja tako nagovarja hispaniste - profesorje, študente, prevajalce - in druge strokovnjake s področja literarnih ved, jezikoslovja in humanistike nasploh. 